\begin{tabular}{c} 
JURNAI RIS'II \\
IAll \\
$\begin{array}{l}\text { (Rekayasa Sistem dan Teknologi Informasi) } \\
\text { Vol.5 No.1 (2021) } 17-23\end{array}$ \\
\hline
\end{tabular}

\title{
Klasifikasi Ujaran Kebencian pada Media Sosial Twitter Menggunakan Support Vector Machine
}

\author{
Oryza Habibie Rahman ${ }^{1}$, Gunawan Abdillah' ${ }^{2}$, Agus Komarudin ${ }^{3}$ \\ 1,2,3 Teknik Informatika, Fakultas Sains dan Informatika, Universitas Jenderal Achmad Yani \\ ${ }^{1}$ oryza.habibie@gmail.com*, ${ }^{2}$ abi_zakiyy@yahoo.com, ${ }^{3}$ agus.komarudin@lecture.unjani.ac.id
}

\begin{abstract}
Nowadays social media has become a place for peoples to express their opinions, there are many ways that can be done to express both positive and negative opinions. Hate speech is one of the problems that we find quite a lot in cyberspace, that things can be detrimental to many parties. Twitter as one of social media, can be used as a source of analysis about people's behavior in cyberspace. Many of our society that unconsciously act of hate speech on social media, therefore this study finds out how people's behavior patterns in cyberspace and the main issue of hate speech on a particular topic and time period by classify it into five classes, namely ethnicity, religion, race, inter-groups and neutral using Support Vector Machine. In this study also compares three kernel that common to use and the result is the system can classify hate speech by using RBF kernel and got the highest result with 93\% accuracy on 700 data train and 300 data test.
\end{abstract}

Keywords: classification, support vector machine, hate speech, twitter, kernel

\begin{abstract}
Abstrak
Saat ini media sosial telah menjadi sarana bagi masyarakat untuk menyampaikan pendapat yang mereka miliki, terdapat banyak cara yang dapat dilakukan untuk menyampaikan pendapat tersebut dari yang bersifat positif maupun negatif. Ujaran kebencian merupakan salah satu masalah yang cukup banyak kita temukan di dunia maya, perilaku tersebut dapat merugikan pihak tertentu. Twitter sebagai salah satu platform yang dapat digunakan untuk menyampaikan opini bisa dijadikan sebagai sumber analisis tentang perilaku masyarakat di dunia maya. Banyak dari masyarakat kita yang tidak sadar bahwa mereka telah melakukan tindakan ujaran kebencian di dunia maya, maka dari itu penelitian ini dibuat untuk mengetahui bagaimana pola perilaku masyarakat di dunia maya dan hal yang menjadi isu utama dalam masalah ujaran kebencian pada topik dan kurun waktu tertentu dengan membaginya menjadi lima kelas yaitu suku, agama, ras, antar golongan dan netral menggunakan Support Vector Machine. Dalam penelitian ini juga dilakukan pengujian dengan membandingkan tiga buah kernel yang umum dipakai, dan hasilnya menunjukan bahwa sistem dapat melakukan klasifikasi ujaran kebencian dengan penggunaan kernel RBF yang menghasilkan nilai akurasi paling tinggi yaitu 93\% dengan komposisi data latih sebanyak 700 data dan data uji sebanyak 300 data.
\end{abstract}

Kata kunci: klasifikasi, support vector machine, ujaran kebencian, twitter, kernel

\section{Pendahuluan}

Saat ini penggunaan media sosial dapat dikatakan sebagai salah satu bentuk kegiatan yang tidak bisa dilepaskan dari keseharian kita, media sosial dapat dijadikan sebagai sebuah sarana untuk melakukan komunikasi, berbagi informasi dan juga untuk mengemukakan suatu pendapat, dampak dari Kata yang disampaikan dalam Twitter terkadang tidak penggunaan media sosial dapat memberikan hal yang dituliskan dalam bentuk yang terstruktur, sehingga bersifat positif maupun negatif yang dapat memengaruhi menimbulkan kesulitan dalam menganalisa informasi kehidupan seseorang[1]. Salah satu contoh media sosial tersebut apalagi jika kita harus mengolah data yang yang sering digunakan adalah Twitter, disebutkan oleh jumlahnya tidak sedikit[3], dan kebiasaan masyarakat 
mengutarakan pendapatnya melalui Twitter dapat menangani data yang sangat besar untuk klasifikasi, dijadikan sebagai acuan untuk mengetahui sentimen terutama klasifikasi teks. masyarakat terhadap berbagai topik seperti tokoh publik[4], tempat, situasi, dan lainnya. Sebagai contoh kita bisa melihat respon masyarakat dalam menanggapi suatu kejadian yang sedang viral diberitakan, hal ini dapat digunakan dalam menilai sentimen masyarakat terhadap sebuah topik dan mengetahui sudah sejauh mana tingkat kesadaran masyarakat dalam beretika di dunia maya[5].

Kemudahan bagi seseorang untuk menyampaikan tokenizing, serta stemming pendapat kini dapat diwujudkan melalui media sosial menggunakan TF-IDF untuk mendapatkan nilai yang sehingga diterbitkan Undang-Undang Informasi dan nantinya akan dijadikan sebagai sebuah fitur, lalu setelah Transaksi Elektronik (UU ITE) untuk membatasi ruang itu data akan masuk pada tahapan klasifikasi bagi masyarakat dalam mengutarakan pendapat di dunia menggunakan Support Vector Machine.

maya. Salah satu permasalahan yang masuk ke dalam

UU ITE adalah mengenai ujaran kebencian, berdasarkan data dari Badan Reserse Kriminal Kepolisian Negara Republik Indonesia (Bareskrim Polri) pada 2016 setidaknya ada lima kasus yang dilaporkan setiap harinya, yang berarti terdapat 150 kasus setiap bulannya[6]. Kasus yang ada pada data Bareskrim merupakan data yang masuk ke tingkat pidana saja, padahal tindakan ujaran kebencian masih banyak terjadi di sekitar kita. Oleh karena itu kita perlu menganalisa lebih jauh lagi sudah sejauh mana perilaku buruk masyarakat di dunia maya.

\section{Metode Penelitian}

Penelitian ini diawali dengan proses pengambilan data berupa tweet yang diambil dari media sosial Twitter, data tersebut nantinya akan diberikan label sesuai kelasnya. Sebelum diproses, data akan disiapkan terlebih dahulu melalui praproses dengan beberapa tahapan, setelah itu data masuk ke dalam proses pembobotan menggunakan TF-IDF dan klasifikasi menggunakan Support Vector Machine.

\subsection{Pengumpulan Data Tweet}

Salah satu cara yang dapat dilakukan untuk Pengambilan data dari Twitter dilakukan dengan mendapatkan informasi dari sekumpulan data teks menggunakan sebuah library yang mampu untuk adalah dengan melakukan klasifikasi teks menjadi melakukan crawling data, tujuannya adalah untuk beberapa kategori yang sudah ditentukan sebelumnya mengumpulkan dataset yang berisi data uji serta data berdasarkan data yang kita miliki[7]. Klasifikasi teks latih berupa kalimat ujaran kebencian yang terdiri dari adalah bagian dari text mining, dan merupakan suatu kelas suku, agama, ras, antar golongan dan netral. metode untuk memprediksi kategori kelas dari sebuah Dataset tersebut nantinya akan disimpan ke dalam data. Beberapa contoh metode klasifikasi yang dapat format file CSV, lalu selanjutnya data akan diproses oleh digunakan untuk melakukan klasifikasi teks adalah sistem untuk membangun sebuah model klasifikasi. metode Naive Bayes Classifier (NBC), K-Nearest Format dari data yang diperoleh dapat dilihat pada Tabel Neighbor (KNN), Support Vector Machine (SVM), 1. Logistic Regression hingga Neural Network, namun yang paling umum dan sering digunakan untuk klasifikasi teks adalah NBC dan SVM[8]. Performa dari algoritma yang digunakan untuk klasifikasi teks tersebut sangat dipengaruhi oleh jenis data dan juga pemilihan fitur, terdapat beberapa teknik untuk melakukan ekstraksi fitur seperti N-gram, Term Frequencey Inverse Document Frequency (TF-IDF), dan Word2Vec.

Dalam penelitian sebelumnya mengenai perbandingan penggunaan beberapa metode dalam klasifikasi teks menunjukan bahwa SVM merupakan metode yang efektif untuk klasifikasi teks, hasil pengujian dari metode SVM pada klasifikasi teks yang dibagi menjadi empat kategori menunjukan nilai rata-rata accuracy rate sebesar 90,72\%, recall rate sebesar $86,37 \%$, dan F1Value sebesar $88,97 \%$. Berdasarkan nilai tersebut maka SVM dapat dikatakan memiliki performa yang stabil dibandingkan metode yang lainnya[9]. Kelebihan dari algoritma ini adalah memiliki kemampuan yang dapat

Tabel 1. Format Dataset

\begin{tabular}{|c|c|c|}
\hline ID & Teks & Timestamp \\
\hline 1 & $\begin{array}{l}\text { kamu katro. Adat jawa } \\
\text { banget. Seminggu sebelum } \\
\text { hari H mempelai wanita di } \\
\text { kurung gakboleh berkontak } \\
\text { langsung dengan cowonya }\end{array}$ & $\begin{array}{c}05 / 03 / 2020 \\
21: 59: 33\end{array}$ \\
\hline 2 & $\begin{array}{l}\text { Ente khan Kristen \#KAFIR, } \\
\text { Jangan terlalu jauh lah } \\
\text { ngurusin soal agama kami } \\
\text { Islam, nanti ente tersesat } \\
\text { dengan kebodohan ente } \\
\text { sendiri. }\end{array}$ & $\begin{array}{c}02 / 03 / 2020 \\
16: 58: 04\end{array}$ \\
\hline 3 & $\begin{array}{l}\text { Pemain cina main kasar } \\
\text { macam babi haha }\end{array}$ & $\begin{array}{c}03 / 03 / 2020 \\
12: 58: 29\end{array}$ \\
\hline$\cdots$ & . & .......... \\
\hline 999 & $\begin{array}{l}\text { Siapa saja yg dukung } \\
\text { Penista Agama adalah } \\
\text { Bajingan yg perlu di ludahi } \\
\text { muka nya - ADP }\end{array}$ & $\begin{array}{c}01 / 03 / 2020 \\
09: 57: 27\end{array}$ \\
\hline
\end{tabular}




\begin{tabular}{llll}
\hline 1000 & Pak Jokowi sangat baik & 04/03/2020 \\
& sering bagi-bagi sepeda & $17: 57: 27$ \\
& kepada anak-anak yang & \\
butuh & & \\
\hline
\end{tabular}

\subsection{Pelabelan Data}

Pada tahap ini dimaksudkan untuk mengubah data unsupervised menjadi data supervised untuk proses pembelajaran mesin. Pelabelan dilakukan dengan cara menentukan kalimat ujaran kebencian dalam tabel dataset oleh annotator yang nantinya akan memberikan label suku, agama, ras, antar golongan atau netral. Setelah itu hasil dari proses pelabelan akan disimpan di dalam database, proses pelabelan data dapat dilihat pada Gambar 1 .

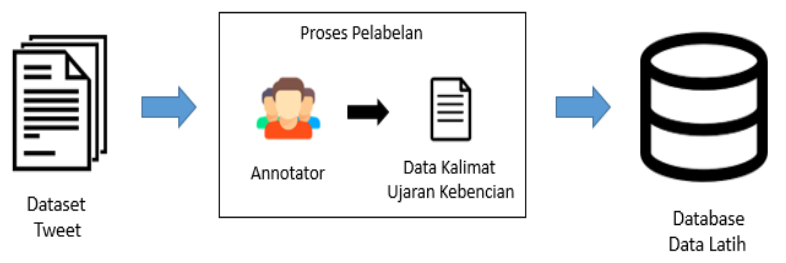

Gambar 1. Proses Pelabelan Tweet

Selanjutnya data latih yang berada dalam database nantinya akan digunakan untuk proses pemodelan klasifikasi kalimat ujaran kebencian menggunakan SVM. Gambaran dari tabel yang ada pada database dapat dilihat pada Tabel 2 .

Tabel 2. Data Latih Berlabel

\begin{tabular}{|c|c|c|}
\hline ID & Teks & Kelas \\
\hline 1 & $\begin{array}{l}\text { kamu katro. Adat jawa } \\
\text { banget. Seminggu sebelum } \\
\text { hari H mempelai wanita di } \\
\text { kurung gakboleh berkontak } \\
\text { langsung dengan cowonya }\end{array}$ & Suku \\
\hline 2 & $\begin{array}{l}\text { Ente khan Kristen \#KAFIR, } \\
\text { Jangan terlalu jauh lah } \\
\text { ngurusin soal agama kami } \\
\text { Islam, nanti ente tersesat } \\
\text { dengan kebodohan ente } \\
\text { sendiri. }\end{array}$ & Agama \\
\hline 3 & $\begin{array}{l}\text { Pemain cina main kasar } \\
\text { macam babi haha }\end{array}$ & Ras \\
\hline 999 & $\begin{array}{l}\text { Siapa saja yg dukung Penista } \\
\text { Agama adalah Bajingan yg } \\
\text { perlu di ludahi muka nya - } \\
\text { ADP }\end{array}$ & $\begin{array}{c}\text { Antar } \\
\text { Golongan }\end{array}$ \\
\hline 1000 & $\begin{array}{l}\text { Pak Jokowi sangat baik sering } \\
\text { bagi-bagi sepeda kepada } \\
\text { anak-anak yang butuh }\end{array}$ & Netral \\
\hline
\end{tabular}

\subsection{Tahapan Praproses}

Langkah awal sebelum suatu data teks diproses lebih lanjut adalah melakukan praproses teks, tujuannya adalah untuk menggali, mengolah dan mengatur data[10]. Pada klasifikasi teks, tahapan praproses dan pemilihan fitur memiliki peran penting yang memengaruhi hasil akurasi untuk tiap metode[11]. Tahapan praproses dilakukan untuk mempersiapkan data agar data teks dapat menjadi lebih terstruktur dengan cara menghilangkan noise yang terdapat pada data sehingga mempermudah dalam proses klasifikasi.
Pada penelitian ini praproses menggunakan beberapa tahapan yang meliputi case folding, tokenizing, filtering, dan stemming.

Case folding digunakan untuk mengkonversi keseluruhan teks dalam dokumen menjadi suatu bentuk yang seragam, fungsi dari case folding ini adalah membuat semua huruf dalam dokumen menjadi huruf kecil. Contoh dari penggunaan case folding dapat dilihat pada Tabel 3.

Tabel 3. Tahapan Case Folding

\begin{tabular}{|l|l|}
\hline \multicolumn{1}{|c|}{ Tweet Asli } & \multicolumn{1}{|c|}{ Tweet Hasil Case Folding } \\
\hline $\begin{array}{l}\text { Gubernur Jawa Barat Ridwan } \\
\text { Kamil apresiasi gerakan } \\
\text { penghijauan di GBLA }\end{array}$ & $\begin{array}{l}\text { gubernur jawa barat ridwan } \\
\text { kamil apresiasi gerakan } \\
\text { penghijauan di gbla }\end{array}$ \\
\hline
\end{tabular}

Tokenizing digunakan untuk memecah sekumpulan karakter dalam suatu teks ke dalam satuan kata, tujuannya adalah untuk mendapatkan fitur dari setiap dokumen setelah diberikan bobot nilai. Contoh dari tahapan tokenizing dapat dilihat pada Tabel 4.

Tabel 4. Tahapan Tokenizing

\begin{tabular}{|c|c|}
\hline Tweet & Token \\
\hline \multirow{5}{*}{$\begin{array}{l}\text { silvi yudho tukang fitnah } \\
\text { politik }\end{array}$} & silvi \\
\hline & yudho \\
\hline & tukang \\
\hline & fitnah \\
\hline & politik \\
\hline
\end{tabular}

Filtering dibutuhkan untuk mengurangi jumlah variabel yang tidak memiliki korelasi tentang ujaran kebencian di setiap dokumen atau biasa disebut dengan stopwords. Tahapan filtering adalah tahap mengambil kata-kata penting dari hasil token, contoh dari penggunaanya dapat dilihat pada Tabel 5.

Tabel 5. Tahapan Filtering

\begin{tabular}{cc}
\hline Tweet & Hasil Filtering \\
\hline yang & - \\
dilakukan & dilakukan \\
oleh & - \\
anies & anies \\
bodoh & bodoh \\
\hline
\end{tabular}

Teknik stemming diperlukan selain untuk memperkecil jumlah indeks yang berbeda dari suatu dokumen, juga untuk melakukan pengelompokan kata-kata lain yang memiliki kata dasar dan arti yang serupa namun memiliki bentuk atau form yang berbeda karena mendapatkan imbuhan yang berbeda. Contoh dari stemming dapat dilihat pada Tabel 6.

Tabel 6. Tahapan Stemming

\begin{tabular}{cc}
\hline Tweet & Hasil Stemming \\
\hline membela & bela \\
dikatakan & kata \\
bodohnya & bodoh \\
dibandingkan & banding \\
\hline
\end{tabular}




\subsection{Pembobotan dan Ekstraksi Fitur TF-IDF}

Setelah praproses selesai, data dari hasil crawling akan diproses untuk dilakukan ekstraksi fitur dan pemberian bobot nilai dengan cara menghitung Term Frequency (TF) yaitu frekuensi dari kemunculan sebuah term dalam dokumen yang bersangkutan dan Inverse Document Frequency (IDF) yaitu sebuah perhitungan dari bagaimana term didistribusikan secara luas pada koleksi dokumen yang bersangkutan. Metode ini sangat populer pada text classification, beberapa pembobotan lainnya merupakan varian dari TF-IDF karena metode ini terkenal efisien, mudah dan memiliki hasil yang akurat[12]. Berikut adalah gambaran dari proses pembobotan fitur TF-IDF yang dapat dilihat pada Gambar 2.

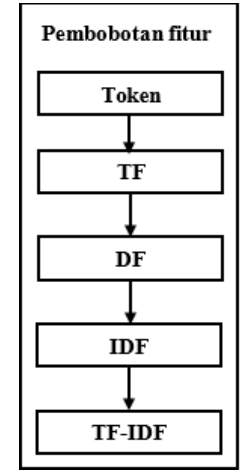

Gambar 2. Proses Pembobotan Fitur

Contoh dari pembobotan fitur menggunakan TF-IDF dilakukan perhitungan dengan menggunakan rumus pada Persamaan 1 dan Persamaan 2.

$$
\begin{aligned}
& w_{i j}=t f_{i j} \times i d f \\
& i d f=\log \left(\frac{N}{d f_{j}}\right)
\end{aligned}
$$

Keterangan:

$\mathrm{i}$ adalah jumlah variable, $\mathrm{j}=$ jumlah data, $\mathrm{w}=$ bobot dokumen dan $\mathrm{N}=$ total dokumen

\subsection{Pembangunan Model dan Klasifikasi Data}

Support Vector Machine (SVM) merupakan metode pembelajaran supervised yang menganalisis data dan mengenali pola, digunakan untuk klasifikasi dan regensi[13], SVM bekerja dengan cara mencari hyperplane terbaik dengan memaksimalkan jarak antar kelas, hyperplane adalah sebuah fungsi yang dapat digunakan untuk pemisah antar kelas. Karena SVM adalah sebuah pengklasifikasi, maka kemudian diberi suatu himpunan pelatihan yang masing-masing ditandai sebagai milik salah satu dari kelas kategori, suatu algoritma pelatihan SVM membangun sebuah model yang memprediksi apakah data yang baru diproses merupakan salah satu dalam kategori atau yang lain.

Pada dasarnya SVM adalah pengklasifikasian linier dan bekerja untuk klasifikasi biner, namun selanjutnya dikembangkan agar bisa melakukan pengklasifikasian multiclass dengan menggunakan teknik seperti one vs one, one vs all, dan directed acyclic graph[14]. Selanjutnya untuk dapat bekerja pada problem non-linier dengan memasukkan konsep kernel pada ruang kerja berdimensi tinggi. Pada ruang kerja berdimensi tinggi, akan dicari hyperplane yang dapat memaksimalkan jarak antara kelas data[15].

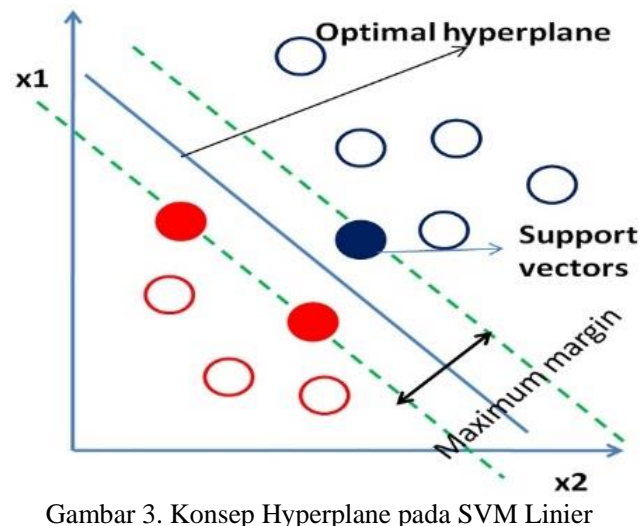

Data yang berada pada bidang pembatas disebut dengan support vector. Pada Gambar 3, dua buah kelas dapat dipisahkan oleh sepasang bidang pembatas sejajar, sehingga diperoleh:

$$
\begin{aligned}
& x_{i} w+b \geq+1, y_{1}=+1 \\
& x_{i} w+b \leq+1, y_{1}=-1
\end{aligned}
$$

Keterangan:

$\mathrm{w}$ adalah normal bidang dan $\mathrm{b}$ adalah posisi bidang alternatif terhadap pusat kordinat

Pada Persamaan 3 dan Persamaan 4 digunakan untuk menentukan kelas dari data yang diklasifikasikan ke dalam kelas 1 atau kelas -1. Untuk konsep dari SVM non-linier dapat dilihat pada Gambar 4.

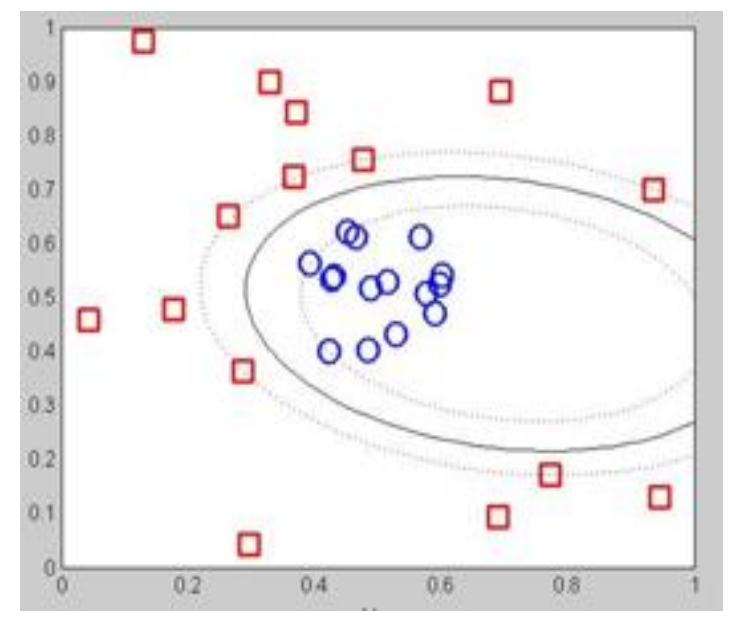

Gambar 4. Konsep SVM Non-Linier 
Konsep dari SVM non-linier yaitu dengan memetakan dalam lima kelas, maka kita perlu membuat lima buah data ke ruang vektor yang berdimensi lebih tinggi, model SVM biner yang akan digunakan untuk sehingga kedua buah kelas dapat dipisahkan secara linier mengklasifikasi kalimat ujaran kebencian dengan cara oleh sebuah hyperplane. Untuk mencari nilai hyperplane melakukan perhitungan yang sama namun dengan yang optimal kita dapat menggunakan formula dari dataset yang berbeda, contoh dari lima buah model SVM lagrange multiplier yang dirumuskan pada Persamaan 5. biner dapat dilihat pada Tabel 7.

$$
L_{d}=\sum_{i=1}^{N} a_{i}-\frac{1}{2} \sum_{i, j} a_{i} a_{j} y_{i} y_{j} x_{i} x_{j}
$$

Untuk menyelesaikan permasalahan pada SVM nonlinier terdapat teknik yang dapat digunakan yaitu dengan menambahkan sebuah fungsi kernel. Dengan menambahkan fungsi kernel pada SVM nantinya data $x$ akan dipetakan ke ruang vektor yang lebih tinggi sehingga data dapat dipisahkan oleh fungsi hyperplane. Beberapa fungsi kernel yang umum digunakan adalah kernel Linear, Sigmoid, Polynomial dan juga Radial Basic Function (RBF).

Setelah melalui tahapan praproses dan pembobotan fitur menggunakan TF-IDF, maka didapatkan jumlah fitur sebanyak 2654 kata dari 1000 data latih dan juga bobot nilai dari setiap fitur. Proses selanjutnya adalah melakukan proses training dengan membangun model SVM dan melakukan klasifikasi menggunakan data uji, gambaran dari proses training dan juga pengujian dapat dilihat pada Gambar 5.

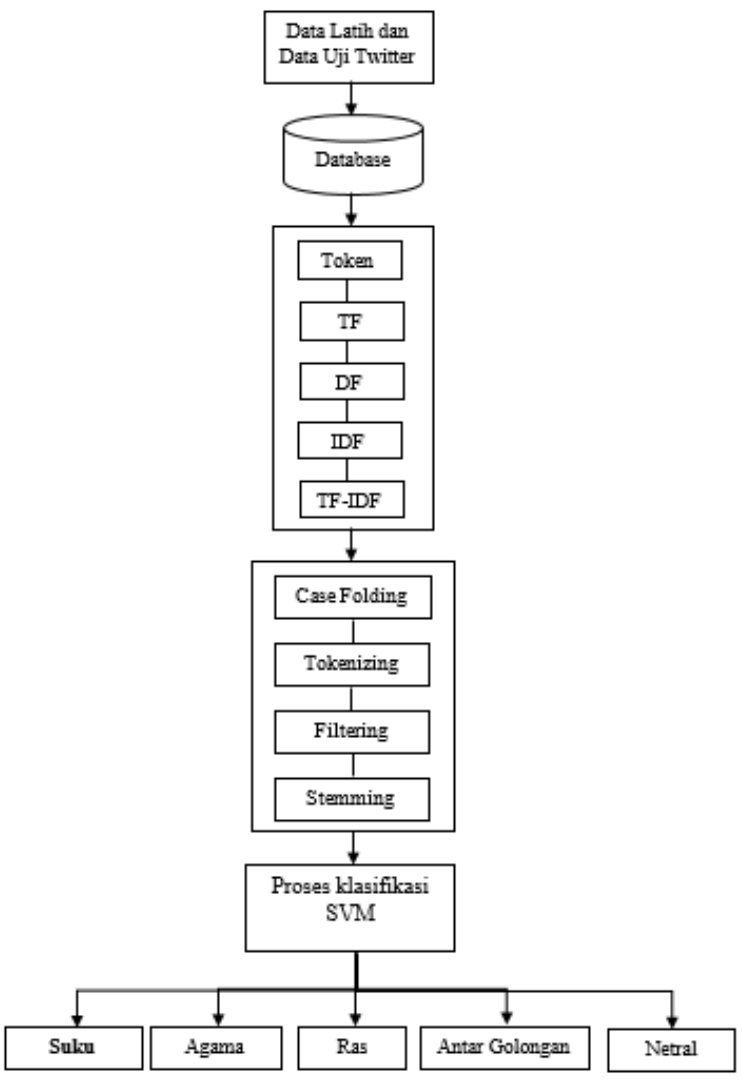

Gambar 5. Gambaran Proses Klasifikasi Ujaran Kebencian

\begin{tabular}{|c|c|c|}
\hline$y_{i}=1$ & $y_{i}=-1$ & Hipotesis \\
\hline Kelas Suku & $\begin{array}{c}\text { Bukan kelas } \\
\text { Suku }\end{array}$ & $F^{1}(x)=\left(W^{1}\right) x+b^{1}$ \\
\hline Kelas Agama & $\begin{array}{c}\text { Bukan kelas } \\
\text { Agama }\end{array}$ & $F^{2}(x)=\left(W^{2}\right) x+b^{2}$ \\
\hline Kelas Ras & $\begin{array}{c}\text { Bukan kelas } \\
\text { Ras }\end{array}$ & $F^{3}(x)=\left(W^{3}\right) x+b^{3}$ \\
\hline $\begin{array}{c}\text { Kelas Antar } \\
\text { Gol }\end{array}$ & $\begin{array}{c}\text { Bukan kelas } \\
\text { Antar Gol }\end{array}$ & $F^{4}(x)=\left(W^{4}\right) x+b^{4}$ \\
\hline Kelas Netral & $\begin{array}{l}\text { Bukan kelas } \\
\text { Netral }\end{array}$ & $F^{5}(x)=\left(W^{5}\right) x+b^{5}$ \\
\hline
\end{tabular}

Selanjutnya setelah semua model SVM telah siap untuk digunakan, langkah berikutnya adalah memasukan data uji untuk diklasifikasikan ke dalam sistem dengan memasukan data ke dalam model hingga nilainya $=1$.

\section{Hasil dan Pembahasan}

Penelitian ini menghasilkan sebuah sistem yang mampu mengumpulkan data tweet yang ingin dianalisa berdasarkan topik dan kurun waktu tertentu. Setelah itu, data yang telah dikumpulkan tersebut dapat diklasifikasikan berdasarkan kelasnya pada sistem klasifikasi ujaran kebencian. Selanjutnya dilakukan pengujian kinerja sistem dengan membandingan tiga buah kernel yang digunakan untuk mencari nilai akurasi tertinggi pada kasus klasifikasi ujaran kebencian.

\subsection{Pencarian dan Pengumpulan Data}

Sistem klasifikasi ujaran kebencian dapat digunakan untuk melakukan pencarian data sesuai dengan topik dan kurun waktu yang diinginkan, sistem dapat melakukan pencarian sesuai dengan inputan dari user untuk selanjutnya disimpan dan diklasifkasikan. Hasil dari proses pencarian dan pengumpulan data dapat dilihat pada Gambar 7.

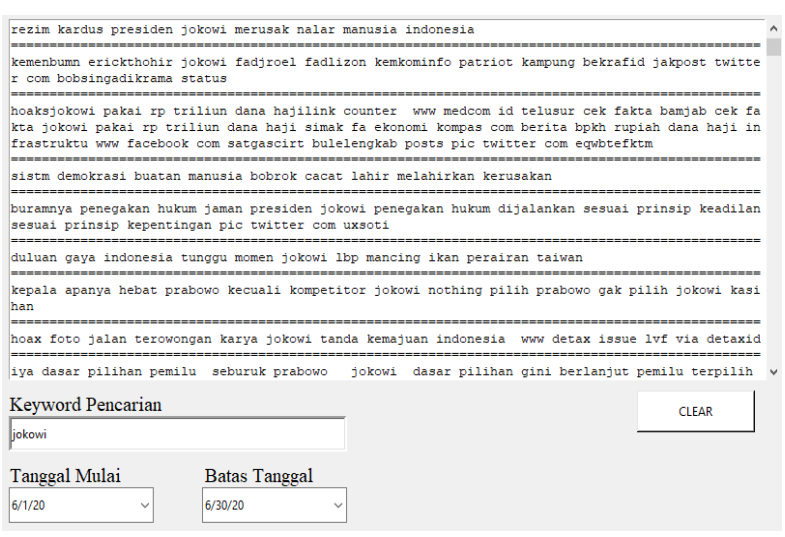

Gambar 7. Hasil Pencarian Data Twitter

Pada penelitian ini digunakan teknik one against all untuk dapat mengklasifikasi kalimat ujaran kebencian ke 


\subsection{Klasifikasi Data}

Setelah melakukan proses pencarian, selanjutnya data yang berhasil dikumpulkan oleh sistem akan diklasifikasikan berdasarkan kelasnya masing-masing. Hasil dari klasifikasi sistem dapat dilihat pada Gambar 8.

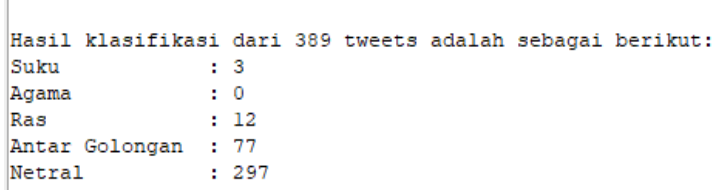

Gambar 8. Hasil Klasifikasi Data

\subsection{Pengujian Kernel}

Pengujian kinerja sistem dilakukan untuk mengetahui nilai dari precision, recall, $F$-measure dan accuracy dari sistem klasifikasi ujaran kebenecian. Pada penelitian ini pengujian dilakukan dengan membandingkan tiga buah kernel yaitu kernel linear, sigmoid dan juga RBF dengan menggunakan 700 data latih dan 300 data uji serta menggunakan nilai $\mathrm{C}=1$, lalu perhitungannya dilakukan menggunakan metode confusion matrix. Hasil dari pengujian kernel linear ditunjukan pada Tabel 8.

Tabel 8. Confusion Matrix Kernel Linear

\begin{tabular}{|c|c|c|c|c|c|c|}
\hline \multirow{6}{*}{ 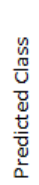 } & \multicolumn{6}{|c|}{ True Class } \\
\hline & & Suku & Agama & Ras & Antar Golongan & Netral \\
\hline & Suku & 50 & 0 & 0 & 0 & 0 \\
\hline & Agama & 0 & 32 & 0 & 2 & 0 \\
\hline & Ras & 0 & 0 & 46 & 0 & 0 \\
\hline & Antar Golongan & 1 & 5 & 1 & 52 & 15 \\
\hline & Netral & 8 & 0 & 1 & 8 & 79 \\
\hline
\end{tabular}

Dari hasil pengujian menggunakan kernel linear yang ditunjukan pada Tabel dan melakukan perhitungan dengan confusion matrix, maka didapatkan nilai rata-rata accuracy sebesar 0.92 , nilai precision sebesar 0.85 , nilai recall sebesar 0.88 , dan $F$-measure sebesar 0.85 . Selanjutnya hasil dari pengujian kernel sigmoid ditunjukan pada Tabel 9.

Tabel 9. Confusion Matrix Kernel Sigmoid

\begin{tabular}{|c|c|c|c|c|c|c|}
\hline \multirow{7}{*}{ 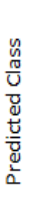 } & \multicolumn{6}{|c|}{ True Class } \\
\hline & & Suku & Agama & Ras & Antar Golongan & Netral \\
\hline & Suku & 47 & 0 & 0 & 0 & 0 \\
\hline & Agama & 0 & 36 & 0 & 3 & 1 \\
\hline & Ras & 0 & 0 & 45 & 1 & 0 \\
\hline & Antar Golongan & 0 & 0 & 1 & 57 & 15 \\
\hline & Netral & 4 & 0 & 1 & 6 & 83 \\
\hline
\end{tabular}

Dari hasil pengujian menggunakan kernel sigmoid yang ditunjukan pada Tabel dan melakukan perhitungan dengan confusion matrix, maka didapatkan nilai rata-rata accuracy sebesar 0.92, nilai precision sebesar 0.90, nilai recall sebesar 0.89 , dan F-measure sebesar 0.87 . Selanjutnya hasil dari pengujian kernel RBF ditunjukan pada Tabel 10.
Tabel 10. Confusion Matrix Kernel Sigmoid

\begin{tabular}{|c|c|c|c|c|c|c|}
\hline \multirow{7}{*}{ 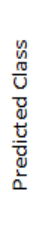 } & \multicolumn{6}{|c|}{ True Class } \\
\hline & & Suku & Agama & Ras & Antar Golongan & Netral \\
\hline & Suku & 51 & 0 & 0 & 0 & 0 \\
\hline & Agama & 0 & 35 & 1 & 0 & 2 \\
\hline & Ras & 0 & 1 & 40 & 0 & 0 \\
\hline & Antar Golongan & 0 & 3 & 3 & 59 & 25 \\
\hline & Netral & 6 & 1 & 0 & 5 & 68 \\
\hline
\end{tabular}

Dari hasil pengujian menggunakan kernel RBF yang ditunjukan pada Tabel 10 dan melakukan perhitungan dengan confusion matrix, maka didapatkan nilai rata-rata accuracy sebesar 0.93 , nilai precision sebesar 0.84 , nilai recall sebesar 0.86 , dan $F$-measure sebesar 0.83 .

Pengujian yang dilakukan dengan membandingkan tiga buah kernel yaitu kernel linear, sigmoid dan juga RBF memiliki perbedaan yang tidak terlalu signifikan pada nilai akurasinya untuk kasus klasifikasi ujaran kebencian dengan 1000 dataset yang terdiri dari 700 data latih dan 300 data uji. Nilai akurasi yang paling tinggi didapatkan dengan menggunakan kernel $\mathrm{RBF}$ dengan nilai $\mathrm{C}=1$ yang menghasilkan nilai rata-rata akurasi sebesar $93 \%$, kernel RBF merupakan kernel yang cukup banyak digunakan untuk permasalahan kasus non-linear pada support vector machine. Untuk keseluruhan hasil pengujian dari ketiga kernel dapat dilihat pada Tabel 11.

Tabel 11. Hasil Pengujian Kernel

\begin{tabular}{|c|c|c|c|c|}
\hline \multirow{2}{*}{ Kernel } & \multicolumn{3}{|c|}{ Average } & \multirow{2}{*}{ F-Measure } \\
\cline { 2 - 5 } & Precision & Recall & Accuracy & \\
\hline Linear & 0.85 & 0.88 & 0.92 & 0.85 \\
\hline Sigmoid & 0.90 & 0.89 & 0.92 & 0.87 \\
\hline RBF & 0.84 & 0.86 & 0.93 & 0.83 \\
\hline
\end{tabular}

\section{Kesimpulan}

Berdasarkan hasil pengujian dengan menggunakan beberapa fungsi kernel dan penggunaan data latih sebanyak 700 data serta data uji sebanyak 300 data, penggunaan kernel RBF menghasilkan nilai accuracy yang paling tinggi di antara kernel linear dan sigmoid. Kernel RBF memiliki nilai accuracy sebesar 93\%, nilai precision sebesar $84 \%$, nilai recall sebesar $86 \%$, dan nilai $F$-measure sebesar $83 \%$. Sistem klasifikasi ujaran kebencian diharapkan dapat membantu menganalisa perilaku masyarakat di dunia maya, yang dilihat berdasarkan hasil keluaran sistem yang selanjutnya dapat dianalisis lebih lanjut.

\section{Daftar Rujukan}

[1] H. Nurrahmi and D. Nurjanah, "Indonesian Twitter Cyberbullying Detection using Text Classification and User Credibility," 2018 International Conference on Information and Communications Technology, ICOIACT 2018, pp. 543-548, 2018.

[2] A. M. Pravina, I. Cholissodin, and P. P. Adikara, "Analisis Sentimen Tentang Opini Maskapai Penerbangan pada Dokumen Twitter Menggunakan Algoritme Support Vector Machine ( SVM )," Jurnal Pengembangan Teknologi Informasi dan Ilmu Komputer (J-PTIIK) Universitas Brawijaya, vol. 3, no. 3, pp. 2789-2797, 2019. 
[3] E. E. Pratama and B. R. Trilaksono, "Klasifikasi Topik Keluhan Pelanggan Berdasarkan Tweet dengan Menggunakan Penggabungan Feature Hasil Ekstraksi pada Metode Support Vector Machine (SVM)," Jurnal Edukasi dan Penelitian Informatika (JEPIN), vol. 1, no. 2, pp. 53-59, 2015.

[4] I. Sunni and D. H. Widyantoro, "Analisis Sentimen dan Ekstraksi Topik Penentu Sentimen pada Opini Terhadap Tokoh Publik," Jurnal Sarjana Institut Teknologi Bandung Bidang Teknik Elektro dan Informatika, vol. 1, no. 2, pp. 200-206, 2012.

[5] G. Vinodhini and R. Chandrasekaran, "Sentiment Analysis and Opinion Mining: A Survey," International Journal of Advanced Research in Computer Science and Software Engineering, vol. 2, no. 6, pp. 282-292, 2012.

[6] I. Afina, R. Mulia, M. I. Fanany, and Y. Ekanata, "Hate Speech Detection in the Indonesian Language: A Dataset and Preliminary Study," 2017 International Conference on Advanced Computer Science and Information Systems(ICACSIS), pp. 233-237, 2017.

[7] V. Korde and C. N. Mahender, "Text Classification and Classifiers:A Survey," International Journal of Artificial Intelligence \& Applications, vol. 3, no. 2, pp. 85-99, 2012.

[8] S. Wang and C. D. Manning, "Baselines and bigrams: Simple, good sentiment and topic classification," 50th Annual Meeting of the Association for Computational Linguistics, ACL 2012 Proceedings of the Conference, vol. 2, no. 1, pp. 90-94, 2012.

[9] Z. Liu, X. Lv, K. Liu, and S. Shi, "Study on SVM compared with the other text classification methods," 2nd International
Workshop on Education Technology and Computer Science, ETCS 2010, vol. 1, pp. 219-222, 2010.

[10] W. A. Luqyana, I. Cholissodin, and R. S. Perdana, "Analisis Sentimen Cyberbullying Pada Komentar Instagram dengan Metode Klasifikasi Support Vector Machine," Jurnal Pengembangan Teknologi Informasi dan Ilmu Komputer ( $J_{-}$ PTIIK) Universitas Brawijaya, vol. 2, no. 11, pp. 4704-4713, 2018.

[11] M. K. Dalal and M. A. Zaveri, "Automatic Text Classification: A Technical Review," International Journal of Computer Applications, vol. 28, no. 2, pp. 37-40, 2011.

[12] S. Fatima, "Text Document Categorization using Support Vector Machine," International Research Journal of Engineering and Technology (IRJET), vol. 4, no. 2, pp. 141147, 2017.

[13] S. K. Lidya, O. S. Sitompul, and S. Efendi, "Sentiment Analysis Pada Teks Bahasa Indonesia Menggunakan Support Vector Machine ( Svm )," Seminar Nasional Teknologi dan Komunikasi 2015, no. Sentika, pp. 1-8, 2015.

[14] Y. Ahuja and S. Kumar Yadav, "Multiclass Classification and Support Vector Machine," Global Journal of Computer Science and Technology Interdisciplinary, vol. 12, no. 11, pp. 14-19, 2012.

[15] R. Moraes, J. F. Valiati, and W. P. Gavião Neto, "Documentlevel sentiment classification: An empirical comparison between SVM and ANN," Expert Systems with Applications, vol. 40, no. 2, pp. 621-633, 2013. 